OPEN ACCESS

Edited by:

Ulrike C. Müller,

Heidelberg University, Germany

Reviewed by:

Peter Soba,

Center for Molecular Neurobiology

(ZMNH), University of Hamburg,

Germany

Doris Kretzschmar,

Oregon Health and Science

University (OHSU), USA

*Correspondence:

Valérie Goguel valerie.goguel@espci.fr

Received: 26 October 2016 Accepted: 28 November 2016 Published: 08 December 2016

Citation:

Preat T and Goguel V (2016) Role of Drosophila Amyloid Precursor Protein

in Memory Formation.

Front. Mol. Neurosci. 9:142

doi: 10.3389/fnmol.2016.00142

\section{Role of Drosophila Amyloid Precursor Protein in Memory Formation}

\author{
Thomas Preat and Valérie Goguel * \\ Genes and Dynamics of Memory Systems, Brain Plasticity Unit, Centre National de la Recherche Scientifique (CNRS), ESPCI \\ Paris, PSL Research University, Paris, France
}

The amyloid precursor protein (APP) is a membrane protein engaged in complex proteolytic pathways. APP and its derivatives have been shown to play a central role in Alzheimer's disease (AD), a progressive neurodegenerative disease characterized by memory decline. Despite a huge effort from the research community, the primary cause of $A D$ remains unclear, making it crucial to better understand the physiological role of the APP pathway in brain plasticity and memory. Drosophila melanogaster is a model system well-suited to address this issue. Although relatively simple, the fly brain is highly organized, sustains several forms of learning and memory, and drives numerous complex behaviors. Importantly, molecules and mechanisms underlying memory processes are conserved from flies to mammals. The fly encodes a single non-essential APP homolog named APP-Like (APPL). Using in vivo inducible RNA interference strategies, it was shown that APPL knockdown in the mushroom bodies (MB)-the central integrative brain structure for olfactory memory - results in loss of memory. Several APPL derivatives, such as secreted and full-length membrane APPL, may play different roles in distinct types of memory phases. Furthermore, overexpression of Drosophila amyloid peptide exacerbates the memory deficit caused by APPL knockdown, thus potentiating memory decline. Data obtained in the fly support the hypothesis that APP acts as a transmembrane receptor, and that disruption of its normal function may contribute to cognitive impairment during early AD.

Keywords: Drosophila melanogaster, amyloid precursor protein, learning, memory, mushroom bodies, conditional expression, amyloid peptide

\section{DROSOPHILA AS A MODEL TO STUDY THE ROLE OF THE APP PATHWAY IN MEMORY}

The initial events leading to Alzheimer's disease (AD) are still unknown. Amyloid deposits, a hallmark of $\mathrm{AD}$, are formed by the aggregation of amyloid peptides $(\mathrm{A} \beta)$ resulting from proteolytic processing of the amyloid precursor protein (APP; Turner et al., 2003). APP is a transmembrane protein that is subjected to two exclusive proteolytic pathways: the non-amyloidogenic pathway initiated by the $\alpha$-secretase producing a secreted APP form (sAPP $\alpha$ ), and the amyloidogenic pathway initiated by the $\beta$-secretase leading to the production of $A \beta$. For many years, the amyloid hypothesis put $\mathrm{A} \beta$ at the center of the etiology of $\mathrm{AD}$ (Hardy and Selkoe, 2002). However, several studies have shown that APP plays a positive role in memory (Meziane et al., 1998; Ring et al., 2007), raising the possibility that aside from A $\beta$ toxicity, APP loss-of-function may participate in $\mathrm{AD}$, particularly during the early stages of the disease characterized by memory impairment. The physiological role of APP is difficult to assess due to its numerous proteolytic metabolites. 
Functional studies of the APP pathway in rodents are also limited due to the redundancy of the three APP-related genes and the lethality of the triple knockout (Heber et al., 2000; Herms et al., 2004). In addition, mouse studies have been essentially performed using constitutive mutants, making it hard to discriminate developmental functions from direct roles in the adult brain. The Drosophila melanogaster genome contains homologs of $75 \%$ of human disease-related genes (Fortini et al., 2000; Reiter et al., 2001). Interestingly, the fly expresses a single non-essential APP ortholog, called APP-Like (APPL). APPL is a neuronal-specific protein particularly expressed in the axonal neuropil of the adult mushroom bodies (MB; Torroja et al., 1996).

Appl-deficient flies $\left(A p p l^{d}\right)$ display phototaxis deficits that are alleviated upon ectopic expression of human APP (hAPP), which is the first demonstration that APPL is an APP ortholog (Luo et al., 1992). APPL/hAPP sequence comparison found homology regions at the E1 and E2 ectodomains and at the C-terminal intracellular domain (Rosen et al., 1989). APPL protein (887 aa) is substantially longer than hAPP (695 aa), largely due to having longer sequences between $\mathrm{E} 1$ and $\mathrm{E} 2$ domains and between $\mathrm{E} 2$ and $\mathrm{A} \beta$ sequences. $\mathrm{A} \beta$ sequences are manifestly not conserved between APP and APPL, and amyloid peptides are not described in wild-type Drosophila. However, a Drosophila $\mathrm{A} \beta$-like peptide $(\mathrm{dA} \beta)$ was identified in old flies overexpressing APPL (Carmine-Simmen et al., 2009). Indeed, APPL overexpression in old age leads to Thioflavin-Spositive aggregates that are associated with neurodegeneration, suggesting that APPL processing produces an analog of human A $\beta$ (Carmine-Simmen et al., 2009). Importantly, APPL undergoes similar proteolytic pathways to APP (Poeck et al., 2011), and the homologs of all mammalian secretases have been characterized in the fly (Rooke et al., 1996; Boulianne et al., 1997; Hong and Koo, 1997; Carmine-Simmen et al., 2009).

Despite its relative simplicity, the fly brain is highly structured and drives sophisticated behaviors. In particular, it is extensively used as a model system to study associative memory. Molecular mechanisms underlying memory are conserved from flies to mammals (McGuire et al., 2005), and the neuronal structures involved are well described (Heisenberg, 2003; Waddell, 2010; Aso et al., 2014a,b). The MB are known as the central integrative brain structure for olfactory associative memory (de Belle and Heisenberg, 1994; Pascual and Préat, 2001; Gerber et al., 2004; Krashes et al., 2007; Gervasi et al., 2010). The MB are a bilateral structure composed of 4000 intrinsic neurons, the Kenyon cells, classed into three subtypes whose axons form two vertical ( $\alpha$ and $\left.\alpha^{\prime}\right)$ and three medial $\left(\beta, \beta^{\prime}\right.$ and $\left.\gamma\right)$ lobes (Crittenden et al., 1998). Using a classical conditioning paradigm in which an odorant is paired with the delivery of electric shocks, the fly is capable of forming six discrete aversive memory phases reflected at neural network level (Bouzaiane et al., 2015). Learning and short-term memory are measured immediately after a single conditioning, while middle-term memory (MTM) is assessed $1-3 \mathrm{~h}$ later. The fly can also produce two antagonistic forms of consolidated memory (Isabel et al., 2004). Long-term anesthesia-resistant memory (LT-ARM) is formed after multiple massed cycles of conditioning, whereas the robust long-term memory (LTM) is only formed after multiple cycles spaced by rest intervals. Crucially, LTM is the only memory phase dependent on de novo protein-synthesis (Tully et al., 1994).

Many human neurodegenerative diseases can be modeled in Drosophila (Bilen and Bonini, 2005). In particular, transgenic flies have been generated to analyze human $A \beta$-induced toxicity. Expression in the Drosophila brain of human $A \beta 42$ resulted in defects similar to that observed in the mouse (Finelli et al., 2004; Greeve et al., 2004; Iijima et al., 2004, 2008; Crowther et al., 2005; Zhao et al., 2010). Thus, similarities between $A \beta$-induced neurotoxic biochemical pathways in flies and humans make Drosophila a relevant model to study the molecular basis of $\mathrm{AD}$ pathogenesis. Neuronal expression of human $A \beta 42$ leads to a learning deficit in young flies, and MTM deficit in older flies (Iijima et al., 2004, 2008; Fang et al., 2012). Likewise, neuronal overexpression of hAPP alters learning and MTM in young flies and these deficits become more pronounced as the fly ages (Sarantseva et al., 2009). hAPP expression in the MB was also shown to alter LTM (Goguel et al., 2011).

APP overexpression-related memory deficits likely result from accumulation of amyloid peptides, especially as it was suggested that the fly secretases can cleave APP (Greeve et al., 2004). Furthermore, the above-cited results were obtained using constitutive overexpression, creating conditions under which APP and/or A $\beta$ accumulate over the entire life of the fly, thus increasing their toxic potential, particularly during developmental stages. In fact, when $\mathrm{dA} \beta$ overexpression is achieved in the MB of adult flies for only 2 days, no MTM deficit is observed (Bourdet et al., 2015a). Taken together, the data suggest that memory impairments observed with constitutive expression of APP result from a developmental defect and/or general neuronal dysfunction rather than from some specific alteration of the molecular mechanisms required to sustain memory formation.

\section{APPL IS REQUIRED FOR SPECIFIC MEMORY PHASES}

$\mathrm{A} \beta$ toxicity has been a focus of research for years, but it now appears essential to better understand APP function in brain physiology. Early on, it was shown that $A p p l^{d}$ flies do not form normal associative learning, but it was impossible to conclude that APPL was involved in this process as the Appld flies did not react normally to electric shock exposure, which was the unconditioned stimulus used for the study (Luo et al., 1992). It was later shown that Appl disruption leads to slight abnormalities in the morphology of the MB lobes ( $\mathrm{Li}$ et al., 2004). More recently, a study demonstrated the role of APPL in brain wiring (Soldano et al., 2013). Thus, functional studies need to rule out possible roles during brain development. One of the major advantages of the Drosophila model is that it can be used to implement inducible loss-of-function studies. Indeed, the expression of any gene of interest can be controlled both spatially (Brand and Perrimon, 1993) and temporally (McGuire et al., 2003). 
Using conditional RNA interference, it was demonstrated that APPL expression in the adult $\mathrm{MB}$ is required for the proper formation of specific memory phases. APPL silencing in the MB of adult flies was shown to disrupt MTM and LTM, but neither learning nor ARM formation was affected (Goguel et al., 2011; Bourdet et al., 2015b). MTM and LTM are two memory phases known to share identical neuronal circuits (Bouzaiane et al., 2015), indicating a role for APPL in these structures. These memory phenotypes are reminiscent of the pattern displayed by amnesiac mutants (Quinn et al., 1979; Feany and Quinn, 1995; DeZazzo et al., 1999; Yu et al., 2006), suggesting that APPL and Amnesiac, a predicted neuropeptide precursor showing homology to an adenylate cyclase-activating peptide (Feany and Quinn, 1995), are involved in the same molecular pathways.

Memory deficits are thus caused by loss of APPL function, independent of the amyloid pathway toxicity. This data further supports the hypothesis that APP downregulation might contribute to early cognitive impairment in $\mathrm{AD}$. To further assess which APPL fragment is required for memory processes, two APPL-mutant forms were used: a constitutively-secreted APPL protein $\left(\mathrm{APPL}^{\mathrm{s}}\right)$ and a non-cleavable secretion-defective form (APPL ${ }^{\text {sd }}$ ). The $A p p l^{s}$ sequence contains a stop codon that generates a soluble 788 -amino-acid $\mathrm{N}$-terminal fragment of APPL, whereas APPL ${ }^{\text {sd }}$ is deleted from the $\alpha$ and $\beta$ cleavage sites, thus preventing its processing (Torroja et al., $1996,1999)$. Consequently, APPL ${ }^{\text {sd }}$ is exclusively expressed as a transmembrane protein. Overexpression of $\mathrm{APPL}^{\mathrm{s}}$ in the adult MB rescued the MTM deficit caused by a reduction of endogenous APPL levels, indicating that a secreted fragment of APPL is involved in memory (Bourdet et al., 2015b). This is consistent with mammalian studies showing a role for sAPP $\alpha$ in memory (Meziane et al., 1998; Bour et al., 2004; Ring et al., 2007; Taylor et al., 2008). Unexpectedly, however, overexpression of the fly $\alpha$-secretase KUZ (Rooke et al., 1996), thought to increase sAPPL $\alpha$ levels, did not rescue the memory deficit caused by APPL partial loss-offunction, and even further exacerbated the MTM impairment (Bourdet et al., 2015b). Interestingly, KUZ overexpression in this context was shown to decrease full-length APPL (fl-APPL) protein levels, prompting the hypothesis that the exacerbation of the memory phenotype resulted from a reduction of fl-APPL levels. Supporting this hypothesis, transient APPL ${ }^{\text {sd }}$ expression in the $\mathrm{MB}$ was also able to restore wild-type MTM in an APPL knockdown background (Bourdet et al., 2015b). Interestingly, neither $\mathrm{APPL}^{\mathrm{s}}$ nor $\mathrm{APPL}^{\text {sd }}$ overexpression rescued the LTM phenotype of APPL partial loss-of-function flies. Although negative results are difficult to interpret, they may indicate distinct molecular APPL requirements for MTM and LTM.

Taken together, the data indicate that both fl-APPL and sAPPL are involved in MTM. This apparently contradicts a previous study showing that $\mathrm{sAPP} \alpha$ could rescue the spatial learning defect of APP knockout mice (Ring et al., 2007). However, the APPL proteins APLP1 and APLP2 were preserved in that study. As the three APP homologs show some functional redundancy (Anliker and Müller, 2006), disruption of full-length APP functions might have been partially fulfilled by APLP1 or APLP2. Memory function cannot therefore be attributed exclusively to $\mathrm{SAPP} \alpha$.

Interestingly, APP may be a receptor for sAPP $\alpha$ (YoungPearse et al., 2008; Gralle et al., 2009). In Drosophila, sAPPL was shown to act as a soluble ligand for neuroprotective functions (Wentzell et al., 2012). Moreover, co-immunoprecipitation experiments from transfected Kc cells uncovered an interaction between fl-APPL and SAPPL, suggesting that SAPPL could be a ligand for fl-APPL (Wentzell et al., 2012). It is thus tempting to speculate that APPL is involved in MTM processes through a sAPPL/fl-APPL ligand/receptor interaction.

\section{A $\beta$ EXACERBATES THE MEMORY DEFICIT CAUSED BY APPL PARTIAL LOSS-OF-FUNCTION IN DROSOPHILA}

Neurotoxic effects of $A \beta$ accumulation have been well documented, and studies have shown that the $\beta$-APP cleavage enzyme, Beta-secretase 1 (BACE1), has a negative impact on memory. In mice models of $\mathrm{AD}$, BACE1 deficiency rescues memory deficits (Ohno et al., 2004, 2007), and conversely, expression of hBACE1 was shown to worsen learning and memory deficits (Rockenstein et al., 2005; Chen et al., 2012). In normal mice, hBACE1 gene knock-in caused AD-relevant cognitive impairment (Plucińska et al., 2014). The authors concluded that low hBACE1 levels were sufficient to cause the formation of toxic $A \beta$ oligomeric assemblies. It is important to note here that hBACE1 knock-in mouse also generated decreased full-length APP levels (Plucińska et al., 2014), a feature that could participate in cognitive impairment. In Drosophila, overexpression of the fly $\beta$-secretase (dBACE; Carmine-Simmen et al., 2009) in the adult MB did not impact MTM (Bourdet et al., 2015a). In contrast, it exacerbated the memory deficit of low-APPL-level flies (Bourdet et al., 2015a). One possibility is that, similar to KUZ overexpression, an increase of dBACE-mediated processing reduces fl-APPL levels, thus aggravating the memory deficit caused by APPL knockdown. Interestingly, similar results were observed with $d A \beta$ : $d A \beta$ expression in adult $M B$ neurons impaired MTM only in an APPL partial loss-of-function background (Bourdet et al., 2015a). It was hypothesized that both $\mathrm{dBACE}$ and $\mathrm{dA} \beta$ expression exacerbate the memory deficit caused by a reduction of APPL levels through similar mechanisms mediated by an increase in $\mathrm{dA} \beta$ production that has knock-on effects on APPL function. Memory would thus be affected by two related processes-APPL downregulation and $A \beta$ toxicity-uncovering a functional link between APPL and $\mathrm{A} \beta$.

\section{A PHYSIOLOGICAL ROLE FOR A $\beta$ IN MEMORY?}

Several reports have shown that at very low physiological concentrations, $\mathrm{A} \beta$ modulates synaptic strength (Kamenetz et al., 2003; Abramov et al., 2009) and enhances memory (Puzzo et al., 2008, 2012; Garcia-Osta and Alberini, 2009; Morley et al., 2010). 
$\mathrm{A} \beta$ appears to be a modulator of synaptic activity requiring a fine balance between production and removal. Neprilysins are the major $A \beta$-degrading enzymes (Iwata et al., 2001) and, as such, are thought to be key to $\mathrm{AD}$. Neprilysin proteins are zinc-dependent endopeptidases known to inactivate small peptides. Their active site faces the extracellular space, and they can be present at presynaptic sites (Fukami et al., 2002; Iwata et al., 2004). Neprilysins play a major role in brain function by terminating neuropeptide signaling at the cell surface, and they are involved in many neuronal processes from axonal regeneration and synaptic plasticity to neuro-inflammation, while at the behavioral level neprilysins have been implicated in motor function, anxiety, circadian rhythms and sleep (Nalivaeva et al., 2012).

The issue of whether neprilysins are involved in memory in non-pathological conditions has been addressed in Drosophila. Four neprilysins are expressed in adult Drosophila brain (Meyer et al., 2011), and we have shown using inducible RNA interference that they are all required for MTM and LTM (Turrel et al., 2016). We have proposed that these neprilysins target several neuropeptides involved in memory processes (Turrel et al., 2016). An attractive hypothesis is that one of these targets might be A $\beta$ peptide derived from physiological APPL processing. Consistently, the memory phenotypes observed after neprilysin silencing are reminiscent of the specific pattern in APPL mutants: only MTM and LTM are impaired, suggesting a functional interaction between neprilysins and APPL. Neprilysin 2 would be a good candidate here, since several studies have shown that it is capable of degrading human A $\beta 42$ (Finelli et al., 2004; Cao et al., 2008).

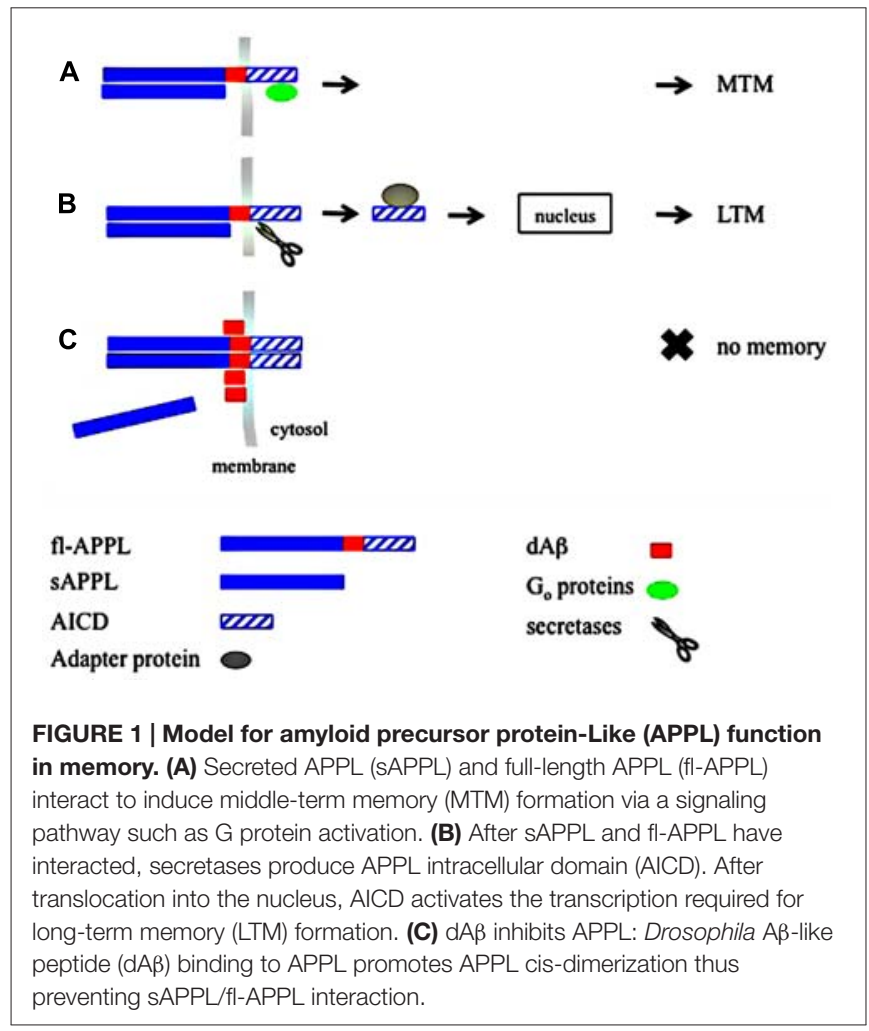

\section{CONCLUSIONS}

In the fly, both sAPPL and fl-APPL are required for MTM, raising the possibility that SAPPL is a ligand of its own precursor (Figure 1). A good candidate acting downstream of APPL could be the $G_{0}$ signaling pathway (Nishimoto et al., 1993; Okamoto et al., 1995; Ramaker et al., 2013). It remains to be determined whether sAPPL and fl-APPL are expressed by the same Kenyon cells, which would point to an autocrine mechanism, or whether fl-APPL is expressed in one specific cell type while sAPPL is secreted from another.

It has been reported that the normal physiological function of APP may be compromised by A $\beta$ (Bignante et al., 2013). Direct interactions between $A \beta$ fibrils and APP were described, with $\mathrm{A} \beta$ acting to enhance APP multimerization, a potentially toxic mechanism (Lorenzo et al., 2000; Van Nostrand et al., 2002; Lu et al., 2003; Shaked et al., 2006; Sola Vigo et al., 2009; Kedikian et al., 2010). dA $\beta$ expression enhances APPL knockdown memory impairment, raising the possibility that $\mathrm{dA} \beta$-induced toxicity may be caused, at least in part, by a physical $d A \beta / A P P L$ interaction. Such a direct interaction could thus promote APPL cis-dimerization, a process that would compromise its function in memory (Figure 1). Furthermore, sAPPL and dA $\beta$ could have opposite functions, as sAPP was shown to disrupt APP dimers (Gralle et al., 2009). Under physiological conditions, dA $\beta$ may also interact with APPL, for example to balance and/or terminate APPL signaling. Characterization of $\mathrm{dA} \beta$ as a neprilysin substrate would support the hypothesis of a physiological role for $\mathrm{dA} \beta$ in memory.

It is not known whether distinct memory phases are supported by distinct APPL-mediated mechanisms. LTM is the only memory phase to depend on transcription regulation (Dubnau et al., 2003; Didelot et al., 2006). Given that APP intracellular domain (AICD), the cleavage product of APP by $\gamma$-secretase, could function as a transcription factor (Cao and Südhof, 2001; Kimberly et al., 2001; Müller et al., 2007), it would be important to know whether the APPL intracellular domain plays a specific role in LTM formation (Figure 1). It has already been reported that AICD production correlates to enhanced plasticity and memory in a TgAPP mice background (Ma et al., 2007).

The vast majority of $\mathrm{AD}$ cases are late-onset, happening to people at age 65 and older. Even though $\mathrm{AD}$ has not been described in Drosophila, the fly nonetheless undergoes an age-related memory impairment (AMI). This AMI exclusively concerns MTM and LTM, as none of the other memory phases decline with age (Tamura et al., 2003; Tonoki and Davis, 2012). Most strikingly, the memory phases affected by APPL knockdown in the MB are precisely those that are lost during fly aging. It is not known whether AMI could be linked to an aging-induced APPL dysfunction. It would be valuable to learn whether APPL expression and/or processing are modified during fly aging. To further explore these issues, the fly offers a suitable simplified system to decipher APP physiological function in learning and memory. 


\section{AUTHOR CONTRIBUTIONS}

VG wrote the manuscript, TP discussed with VG and reviewed the manuscript.

\section{REFERENCES}

Abramov, E., Dolev, I., Fogel, H., Ciccotosto, G. D., Ruff, E., and Slutsky, I. (2009). Amyloid- $\beta$ as a positive endogenous regulator of release probability at hippocampal synapses. Nat. Neurosci. 12, 1567-1576. doi: 10.1038/ nn. 2433

Anliker, B., and Müller, U. (2006). The functions of mammalian amyloid precursor protein and related amyloid precursor-like proteins. Neurodegener. Dis. 3, 239-246. doi: 10.1159/000095262

Aso, Y., Hattori, D., Yu, Y., Johnston, R. M., Iyer, N. A., Ngo, T.T. B., et al. (2014a). The neuronal architecture of the mushroom body provides a logic for associative learning. Elife 3:e04577. doi: 10.7554/eLife. 04577

Aso, Y., Sitaraman, D., Ichinose, T., Kaun, K. R., Vogt, K., Belliart-Guérin, G., et al. (2014b). Mushroom body output neurons encode valence and guide memorybased action selection in Drosophila. Elife 3:e04580. doi: 10.7554/eLife. 04580

Bignante, E. A., Heredia, F., Morfini, G., and Lorenzo, A. (2013). Amyloid $\beta$ precursor protein as a molecular target for amyloid $\beta$-induced neuronal degeneration in Alzheimer's disease. Neurobiol. Aging 34, 2525-2537. doi: 10. 1016/j.neurobiolaging.2013.04.021

Bilen, J., and Bonini, N. M. (2005). Drosophila as a model for human neurodegenerative disease. Annu. Rev. Genet. 39, 153-171. doi: 10. 1146/annurev.genet.39.110304.095804

Boulianne, G. L., Livne-Bar, I., Humphreys, J. M., Liang, Y., Lin, C., Rogaev, E., et al. (1997). Cloning and characterization of the Drosophila presenilin homologue. Neuroreport 8, 1025-1029. doi: 10.1097/00001756-19970303000041

Bour, A., Little, S., Dodart, J.-C., Kelche, C., and Mathis, C. (2004). A secreted form of the $\beta$-amyloid precursor protein (sAPP695) improves spatial recognition memory in OF1 mice. Neurobiol. Learn. Mem. 81, 27-38. doi: 10.1016/s10747427(03)00071-6

Bourdet, I., Lampin-Saint-Amaux, A., Préat, T., and Goguel, V. (2015a). Amyloid$\beta$ peptide exacerbates the memory deficit caused by amyloid precursor protein loss-of-function in Drosophila. PLoS One 10:e0135741. doi: 10.1371/journal. pone.0135741

Bourdet, I., Préat, T., and Goguel, V. (2015b). The full-length form of the Drosophila amyloid precursor protein is involved in memory formation. J. Neurosci. 35, 1043-1051. doi: 10.1523/JNEUROSCI.209314.2015

Bouzaiane, E., Trannoy, S., Scheunemann, L., Plaçais, P.-Y., and Préat, T. (2015). Two independent mushroom body output circuits retrieve the six discrete components of Drosophila aversive memory. Cell Rep. 11, 1280-1292. doi: 10. 1016/j.celrep.2015.04.044

Brand, A. H., and Perrimon, N. (1993). Targeted gene expression as a means of altering cell fates and generating dominant phenotypes. Development 118 , 401-415.

Cao, W., Song, H.-J., Gangi, T., Kelkar, A., Antani, I., Garza, D., et al. (2008). Identification of novel genes that modify phenotypes induced by Alzheimer's $\beta$-amyloid overexpression in Drosophila. Genetics 178, 1457-1471. doi: 10. 1534/genetics.107.078394

Cao, X., and Südhof, T. C. (2001). A transcriptively active complex of APP with Fe65 and histone acetyltransferase tip60. Science 293, 115-120. doi: 10. 1126/science. 1058783

Carmine-Simmen, K., Proctor, T., Tschäpe, J., Poeck, B., Triphan, T., Strauss, R., et al. (2009). Neurotoxic effects induced by the Drosophila amyloid- $\beta$ peptide suggest a conserved toxic function. Neurobiol. Dis. 33, 274-281. doi: 10.1016/j. nbd.2008.10.014

Chen, Y., Huang, X., Zhang, Y.-W., Rockenstein, E., Bu, G., Golde, T. E., et al. (2012). Alzheimer's $\beta$-secretase (BACE1) regulates the cAMP/PKA/CREB pathway independently of $\beta$-amyloid. J. Neurosci. 32, 11390-11395. doi: 10. 1523/JNEUROSCI.0757-12.2012

\section{FUNDING}

This work was supported by the Fondation pour la Recherche Médicale (DEQ20140329540).

Crittenden, J. R., Skoulakis, E. M., Han, K. A., Kalderon, D., and Davis, R. L. (1998). Tripartite mushroom body architecture revealed by antigenic markers. Learn. Mem. 5, 38-51.

Crowther, D. C., Kinghorn, K. J., Miranda, E., Page, R., Curry, J. A., Duthie, F. A. I., et al. (2005). Intraneuronal A $\beta$, non-amyloid aggregates and neurodegeneration in a Drosophila model of Alzheimer's disease. Neuroscience 132, 123-135. doi: 10.1016/j.neuroscience.2004.12.025

de Belle, J. S., and Heisenberg, M. (1994). Associative odor learning in Drosophila abolished by chemical ablation of mushroom bodies. Science 263, 692-695. doi: 10.1126/science. 8303280

DeZazzo, J., Xia, S., Christensen, J., Velinzon, K., and Tully, T. (1999). Developmental expression of an $\mathrm{amn}^{+}$transgene rescues the mutant memory defect of amnesiac adults. J. Neurosci. 19, 8740-8746.

Didelot, G., Molinari, F., Tchénio, P., Comas, D., Milhiet, E., Munnich, A., et al. (2006). Tequila, a neurotrypsin ortholog, regulates long-term memory formation in Drosophila. Science 313, 851-853. doi: 10.1126/science. 1127215

Dubnau, J., Chiang, A.-S., Grady, L., Barditch, J., Gossweiler, S., McNeil, J., et al. (2003). The staufen/pumilio pathway is involved in Drosophila long-term memory. Curr. Biol. 13, 286-296. doi: 10.1016/s0960-9822(03) 00064-2

Fang, L., Duan, J., Ran, D., Fan, Z., Yan, Y., Huang, N., et al. (2012). Amyloid- $\beta$ depresses excitatory cholinergic synaptic transmission in Drosophila. Neurosci. Bull. 28, 585-594. doi: 10.1007/s12264-012-1267-x

Feany, M. B., and Quinn, W. G. (1995). A neuropeptide gene defined by the Drosophila memory mutant amnesiac. Science 268, 869-873. doi: 10. 1126/science. 7754370

Finelli, A., Kelkar, A., Song, H.-J., Yang, H., and Konsolaki, M. (2004). A model for studying Alzheimer's A 342 -induced toxicity in Drosophila melanogaster. Mol. Cell. Neurosci. 26, 365-375. doi: 10.1016/j.mcn.2004.03.001

Fortini, M. E., Skupski, M. P., Boguski, M. S., and Hariharan, I. K. (2000). A survey of human disease gene counterparts in the Drosophila genome. J. Cell Biol. 150, F23-F30. doi: 10.1083/jcb.150.2.f23

Fukami, S., Watanabe, K., Iwata, N., Haraoka, J., Lu, B., Gerard, N. P., et al. (2002). $\mathrm{A} \beta$-degrading endopeptidase, neprilysin, in mouse brain: synaptic and axonal localization inversely correlating with A $\beta$ pathology. Neurosci. Res. 43, 39-56. doi: 10.1016/s0168-0102(02)00015-9

Garcia-Osta, A., and Alberini, C. M. (2009). Amyloid $\beta$ mediates memory formation. Learn. Mem. 16, 267-272. doi: 10.1101/lm.1310209

Gerber, B., Scherer, S., Neuser, K., Michels, B., Hendel, T., Stocker, R. F., et al. (2004). Visual learning in individually assayed Drosophila larvae. J. Exp. Biol. 207, 179-188. doi: 10.1242/jeb.00718

Gervasi, N., Tchénio, P., and Préat, T. (2010). PKA dynamics in a Drosophila learning center: coincidence detection by rutabaga adenylyl cyclase and spatial regulation by dunce phosphodiesterase. Neuron 65, 516-529. doi: 10.1016/j. neuron.2010.01.014

Goguel, V., Belair, A.-L., Ayaz, D., Lampin-Saint-Amaux, A., Scaplehorn, N., Hassan, B. A., et al. (2011). Drosophila amyloid precursor protein-like is required for long-term memory. J. Neurosci. 31, 1032-1037. doi: 10 1523/JNEUROSCI.2896-10.2011

Gralle, M., Botelho, M. G., and Wouters, F. S. (2009). Neuroprotective secreted amyloid precursor protein acts by disrupting amyloid precursor protein dimers. J. Biol. Chem. 284, 15016-15025. doi: 10.1074/jbc.M808755200

Greeve, I., Kretzschmar, D., Tschäpe, J.-A., Beyn, A., Brellinger, C., Schweizer, M., et al. (2004). Age-dependent neurodegeneration and alzheimer-amyloid plaque formation in transgenic Drosophila. J. Neurosci. 24, 3899-3906. doi: 10. 1523/JNEUROSCI.0283-04.2004

Hardy, J., and Selkoe, J. (2002). The amyloid hypothesis of Alzheimer's disease: progress and problems on the road to therapeutics. Science 297, 353-356. doi: $10.1126 /$ science. 1072994

Heber, S., Herms, J., Gajic, V., Hainfellner, J., Aguzzi, A., Rülicke, T., et al. (2000). Mice with combined gene knock-outs reveal essential and partially 
redundant functions of amyloid precursor protein family members. J. Neurosci. 20, 7951-7963.

Heisenberg, M. (2003). Mushroom body memoir: from maps to models. Nat. Rev. Neurosci. 4, 266-275. doi: 10.1038/nrn1074

Herms, J., Anliker, B., Heber, S., Ring, S., Fuhrmann, M., Kretzschmar, H., et al. (2004). Cortical dysplasia resembling human type 2 lissencephaly in mice lacking all three APP family members. EMBO J. 23, 4106-4115. doi: 10.1038/sj. emboj.7600390

Hong, C. S., and Koo, E. H. (1997). Isolation and characterization of Drosophila presenilin homolog. Neuroreport 8, 665-668. doi: 10.1097/00001756199702100-00017

Iijima, K., Chiang, H.-C., Hearn, S. A., Hakker, I., Gatt, A., Shenton, C., et al. (2008). A $\beta 42$ Mutants with different aggregation profiles induce distinct pathologies in Drosophila. PLoS One 3:e1703. doi: 10.1371/journal.pone. 0001703

Iijima, K., Liu, H.-P., Chiang, A.-S., Hearn, S. A., Konsolaki, M., and Zhong, Y. (2004). Dissecting the pathological effects of human $A \beta 40$ and $A \beta 42$ in Drosophila: a potential model for Alzheimer's disease. Proc. Natl. Acad. Sci. U S A 101, 6623-6628. doi: 10.1073/pnas.0400895101

Isabel, G., Pascual, A., and Préat, T. (2004). Exclusive consolidated memory phases in Drosophila. Science 304, 1024-1027. doi: 10.1126/science. 1094932

Iwata, N., Mizukami, H., Shirotani, K., Takaki, Y., Muramatsu, S., Lu, B., et al. (2004). Presynaptic localization of neprilysin contributes to efficient clearance of amyloid- $\beta$ peptide in mouse brain. J. Neurosci. 24, 991-998. doi: 10. 1523/JNEUROSCI.4792-03.2004

Iwata, N., Tsubuki, S., Takaki, Y., Shirotani, K., Lu, B., Gerard, N. P., et al. (2001). Metabolic regulation of brain A $\beta$ by neprilysin. Science 292, 1550-1552. doi: 10 . $1126 /$ science. 1059946

Kamenetz, F., Tomita, T., Hsieh, H., Seabrook, G., Borchelt, D., Iwatsubo, T., et al. (2003). APP processing and synaptic function. Neuron 37, 925-937. doi: 10. 1016/s0896-6273(03)00124-7

Kedikian, G., Heredia, F., Salvador, V. R., Raimunda, D., Isoardi, N., Heredia, L., et al. (2010). Secreted amyloid precursor protein and holo-APP bind amyloid $\beta$ through distinct domains eliciting different toxic responses on hippocampal neurons. J. Neurosci. Res. 88, 1795-1803. doi: 10.1002/jnr.22347

Kimberly, W. T., Zheng, J. B., Guénette, S. Y., and Selkoe, D. J. (2001). The intracellular domain of the $\beta$-amyloid precursor protein is stabilized by Fe65 and translocates to the nucleus in a notch-like manner. J. Biol. Chem. 276, 40288-40292. doi: 10.1074/jbc.C100447200

Krashes, M. J., Keene, A. C., Leung, B., Armstrong, J. D., and Waddell, S. (2007). Sequential use of mushroom body neuron subsets during Drosophila odor memory processing. Neuron 53, 103-115. doi: 10.1016/j.neuron.2006. 11.021

Li, Y., Liu, T., Peng, Y., Yuan, C., and Guo, A. (2004). Specific functions of Drosophila amyloid precursor-like protein in the development of nervous system and nonneural tissues. J. Neurobiol. 61, 343-358. doi: 10.1002/neu. 20048

Lorenzo, A., Yuan, M., Zhang, Z., Paganetti, P. A., Sturchler-Pierrat, C., Staufenbiel, M., et al. (2000). Amyloid $\beta$ interacts with the amyloid precursor protein: a potential toxic mechanism in Alzheimer's disease. Nat. Neurosci. 3, 460-464. doi: 10.1038/74833

Lu, D. C., Shaked, G. M., Masliah, E., Bredesen, D. E., and Koo, E. H. (2003). Amyloid $\beta$ protein toxicity mediated by the formation of amyloid- $\beta$ protein precursor complexes. Ann. Neurol. 54, 781-789. doi: 10.1002/ana.10761

Luo, L., Tully, T., and White, K. (1992). Human amyloid precursor protein ameliorates behavioral deficit of flies deleted for Appl gene. Neuron 9, 595-605. doi: 10.1016/0896-6273(92)90024-8

Ma, H., Lesné, S., Kotilinek, L., Steidl-Nichols, J. V., Sherman, M., Younkin, L., et al. (2007). Involvement of $\beta$-site APP cleaving enzyme 1 (BACE1) in amyloid precursor protein-mediated enhancement of memory and activity-dependent synaptic plasticity. Proc. Natl. Acad. Sci. U S A 104, 8167-8172. doi: 10. 1073/pnas.0609521104

McGuire, S. E., Deshazer, M., and Davis, R. L. (2005). Thirty years of olfactory learning and memory research in Drosophila melanogaster. Prog. Neurobiol. 76, 328-347. doi: 10.1016/j.pneurobio.2005.09.003

McGuire, S. E., Le, P. T., Osborn, A. J., Matsumoto, K., and Davis, R. L. (2003). Spatiotemporal rescue of memory dysfunction in Drosophila. Science 302, 1765-1768. doi: 10.1126/science.1089035
Meyer, H., Panz, M., Albrecht, S., Drechsler, M., Wang, S., Hüsken, M., et al. (2011). Drosophila metalloproteases in development and differentiation: the role of ADAM proteins and their relatives. Eur. J. Cell Biol. 90, 770-778. doi: 10. 1016/j.ejcb.2011.04.015

Meziane, H., Dodart, J. C., Mathis, C., Little, S., Clemens, J., Paul, S. M., et al. (1998). Memory-enhancing effects of secreted forms of the $\beta$-amyloid precursor protein in normal and amnestic mice. Proc. Natl. Acad. Sci. U S A 95, 12683-12688. doi: 10.1073/pnas.95.21.12683

Morley, J. E., Farr, S. A., Banks, W. A., Johnson, S. N., Yamada, K. A., and Xu, L. (2010). A physiological role for amyloid- $\beta$ protein:enhancement of learning and memory. J. Alzheimers Dis. 19, 441-449. doi: 10.3233/JAD-2009-1230

Müller, T., Concannon, C. G., Ward, M. W., Walsh, C. M., Tirniceriu, A. L., Tribl, F., et al. (2007). Modulation of gene expression and cytoskeletal dynamics by the amyloid precursor protein intracellular domain (AICD). Mol. Biol. Cell. 18, 201-210. doi: 10.1091/mbc.e06-04-0283

Nalivaeva, N. N., Belyaev, N. D., Zhuravin, I. A., and Turner, A. J. (2012). The Alzheimer's amyloid-degrading peptidase, neprilysin: can we control it? Int. J. Alzheimers Dis. 2012:383796. doi: 10.1155/2012/383796

Nishimoto, I., Okamoto, T., Matsuura, Y., Takahashi, S., Murayama, Y., and Ogata, E. (1993). Alzheimer amyloid protein precursor complexes with brain GTP-binding protein $\mathrm{G}_{o}$. Nature 362, 75-79. doi: 10.1038/362075a0

Ohno, M., Cole, S. L., Yasvoina, M., Zhao, J., Citron, M., Berry, R., et al. (2007). BACE1 gene deletion prevents neuron loss and memory deficits in 5XFAD APP/PS1 transgenic mice. Neurobiol. Dis. 26, 134-145. doi: 10.1016/j.nbd.2006. 12.008

Ohno, M., Sametsky, E. A., Younkin, L. H., Oakley, H., Younkin, S. G., Citron, M., et al. (2004). BACE1 deficiency rescues memory deficits and cholinergic dysfunction in a mouse model of Alzheimer's disease. Neuron 41, 27-33. doi: 10.1016/s0896-6273(03)00810-9

Okamoto, T., Tadeka, S., Murayama, Y., Ogata, E., and Nishimoto, I. (1995). Ligand-dependent G-protein coupling function of amyloid transmembrane precursor. J. Biol. Chem. 270, 4205-4208. doi: 10.1074/jbc.270.9.4205

Pascual, A., and Préat, T. (2001). Localization of long-term memory within the Drosophila mushroom body. Science 294, 1115-1117. doi: 10.1126/science. 1064200

Plucińska, K., Crouch, B., Koss, D., Robinson, L., Siebrecht, M., Riedel, G., et al. (2014). Knock-in of human BACE1 cleaves murine APP and reiterates Alzheimer-like phenotypes. J. Neurosci. 34, 10710-10728. doi: 10. 1523/JNEUROSCI.0433-14.2014

Poeck, B., Strauss, R., and Kretzschmar, D. (2011). Analysis of amyloid precursor protein function in Drosophila melanogaster. Exp. Brain Res. 217, 413-421. doi: 10.1007/s00221-011-2860-3

Puzzo, D., Privitera, L., Leznik, E., Fà, M., Staniszewski, A., Palmeri, A., et al. (2008). Picomolar amyloid- $\beta$ positively modulates synaptic plasticity and memory in hippocampus. J. Neurosci. 28, 14537-14545. doi: 10. 1523/JNEUROSCI.2692-08.2008

Puzzo, D., Privitera, L., and Palmeri, A. (2012). Hormetic effect of amyloid- $\beta$ peptide in synaptic plasticity and memory. Neurobiol. Aging 33, 1484.e15-1484.e24. doi: 10.1016/j.neurobiolaging.2011.12.020

Quinn, W. G., Sziber, P. P., and Booker, R. (1979). The Drosophila memory mutant amnesiac. Nature 277, 212-214. doi: 10.1038/277212a0

Ramaker, J. M., Swanson, T. L., and Copenhaver, P. F. (2013). Amyloid precursor proteins interact with the heterotrimeric $\mathrm{G}$ protein Go in the control of neuronal migration. J. Neurosci. 33, 10165-10181. doi: 10.1523/jneurosci.114613.2013

Reiter, L. T., Potocki, L., Chien, S., Gribskov, M., and Bier, E. (2001). A systematic analysis of human disease-associated gene sequences in Drosophila melanogaster. Genome Res. 11, 1114-1125. doi: 10.1101/gr.169101

Ring, S., Weyer, S. W., Kilian, S. B., Waldron, E., Pietrzik, C. U., Filippov, M. A., et al. (2007). The secreted $\beta$-amyloid precursor protein ectodomain APPs is sufficient to rescue the anatomical, behavioral and electrophysiological abnormalities of APP-deficient mice. J. Neurosci. 27, 7817-7826. doi: 10. 1523/JNEUROSCI.1026-07.2007

Rockenstein, E., Mante, M., Alford, M., Adame, A., Crews, L., Hashimoto, M., et al. (2005). High $\beta$-secretase activity elicits neurodegeneration in transgenic mice despite reductions in amyloid- $\beta$ levels: implications for the treatment of Alzheimer disease. J. Biol. Chem. 280, 32957-32967. doi: 10.1074/jbc. M507016200 
Rooke, J., Pan, D., Xu, T., and Rubin, G. M. (1996). KUZ, a conserved metalloprotease-disintegrin protein with two roles in Drosophila neurogenesis. Science 273, 1227-1231. doi: 10.1126/science.273.5279.1227

Rosen, D. R., Martin-Morris, L., Luo, L. Q., and White, K. (1989). A Drosophila gene encoding a protein resembling the human beta-amyloid protein precursor. Proc. Natl. Acad. Sci. U S A 86, 2478-2482. doi: 10.1073/pnas.86. 7.2478

Sarantseva, S., Timoshenko, S., Bolshakova, O., Karaseva, E., Rodin, D., Schwarzman, A. L., et al. (2009). Apolipoprotein E-mimetics inhibit neurodegeneration and restore cognitive functions in a transgenic Drosophila model of Alzheimer's disease. PLoS One 4:e8191. doi: 10.1371/journal.pone. 0008191

Shaked, G. M., Kummer, M. P., Lu, D. C., Galvan, V., Bredesen, D. E., and Koo, E. H. (2006). A $\beta$ induces cell death by direct interaction with its cognate extracellular domain on APP (APP 597-624). FASEB J. 20, 1254-1256. doi: 10. 1096/fj.05-5032fje

Sola Vigo, F., Kedikian, G., Heredia, L., Heredia, F., Añel, A. D., Rosa, A. L., et al. (2009). Amyloid- $\beta$ precursor protein mediates neuronal toxicity of amyloid $\beta$ through Go protein activation. Neurobiol. Aging 30, 1379-1392. doi: 10.1016/j. neurobiolaging.2007.11.017

Soldano, A., Okray, Z., Janovska, P., Tmejová, K., Reynaud, E., Claeys, A., et al. (2013). The Drosophila homologue of the amyloid precursor protein is a conserved modulator of Wnt PCP signaling. PLoS Biol. 11:e1001562. doi: 10. 1371/journal.pbio.1001562

Tamura, T., Chiang, A.-S., Ito, N., Liu, H.-P., Horiuchi, J., Tully, T., et al. (2003). Aging specifically impairs amnesiac-dependent memory in Drosophila. Neuron 40, 1003-1011. doi: 10.1016/S0896-6273(03)00732-3

Taylor, C. J., Ireland, D. R., Ballagh, I., Bourne, K., Marechal, N. M., Turner, P. R., et al. (2008). Endogenous secreted amyloid precursor protein$\alpha$ regulates hippocampal NMDA receptor function, long-term potentiation and spatial memory. Neurobiol. Dis. 31, 250-260. doi: 10.1016/j.nbd.2008. 04.011

Tonoki, A., and Davis, R. L. (2012). Aging impairs intermediate-term behavioral memory by disrupting the dorsal paired medial neuron memory trace. Proc. Natl. Acad. Sci. U S A 109, 6319-6324. doi: 10.1073/pnas.11181 26109

Torroja, L., Chu, H., Kotovsky, I., and White, K. (1999). Neuronal overexpression of APPL, the Drosophila homologue of the amyloid precursor protein (APP), disrupts axonal transport. Curr. Biol. 9, 489-493. doi: 10.1016/s09609822(99)80215-2

Torroja, L., Luo, L., and White, K. (1996). APPL, the Drosophila member of the APP-family, exhibits differential trafficking and processing in CNS neurons. J. Neurosci. 16, 4638-4650.
Tully, T., Preat, T., Boynton, S. C., and Del Vecchio, M. (1994). Genetic dissection of consolidated memory in Drosophila. Cell 79, 35-47. doi: 10.1016/00928674(94)90398-0

Turner, P. R., O'Connor, K., Tate, W. P., and Abraham, W. C. (2003). Roles of amyloid precursor protein and its fragments in regulating neural activity, plasticity and memory. Prog. Neurobiol. 70, 1-32. doi: 10.1016/s03010082(03)00089-3

Turrel, O., Lampin-Saint-Amaux, A., Préat, T., and Goguel, V. (2016). Drosophila neprilysins are involved in middle-term and long-term memory. J. Neurosci. 36, 9535-9546. doi: 10.1523/JNEUROSCI.3730-15.2016

Van Nostrand, W. E., Melchor, J. P., Keane, D. M., Saporito-Irwin, S. M., Romanov, G., Davis, J., et al. (2002). Localization of a fibrillar amyloid $\beta$-protein binding domain on its precursor. J. Biol. Chem. 277, 36392-36398. doi: 10. 1074/jbc.M204676200

Waddell, S. (2010). Dopamine reveals neural circuit mechanisms of fly memory. Trends Neurosci. 33, 457-464. doi: 10.1016/j.tins.2010.07.001

Wentzell, J. S., Bolkan, B. J., Carmine-Simmen, K., Swanson, T. L., Musashe, D. T., and Kretzschmar, D. (2012). Amyloid precursor proteins are protective in Drosophila models of progressive neurodegeneration. Neurobiol. Dis. 46, 78-87. doi: 10.1016/j.nbd.2011.12.047

Young-Pearse, T. L., Chen, A. C., Chang, R., Marquez, C., and Selkoe, D. J. (2008). Secreted APP regulates the function of full-length APP in neurite outgrowth through interaction with integrin beta1. Neural Dev. 3:15. doi: 10.1186/17498104-3-15

Yu, D., Akalal, D.-B. G., and Davis, R. L. (2006). Drosophila $\alpha / \beta$ mushroom body neurons form a branch-specific, long-term cellular memory trace after spaced olfactory conditioning. Neuron 52, 845-855. doi: 10.1016/j.neuron.2006. 10.030

Zhao, X. L., Wang, W. A., Tan, J. X., Huang, J. K., Zhang, X., Zhang, B. Z., et al. (2010). Expression of $\beta$-amyloid induced age-dependent presynaptic and axonal changes in Drosophila. J. Neurosci. 30, 1512-1522. doi: 10. 1523/JNEUROSCI.3699-09.2010

Conflict of Interest Statement: The authors declare that the research was conducted in the absence of any commercial or financial relationships that could be construed as a potential conflict of interest.

Copyright (c) 2016 Preat and Goguel. This is an open-access article distributed under the terms of the Creative Commons Attribution License (CC BY). The use, distribution and reproduction in other forums is permitted, provided the original author(s) or licensor are credited and that the original publication in this journal is cited, in accordance with accepted academic practice. No use, distribution or reproduction is permitted which does not comply with these terms. 